\title{
信州大学附属図書館医学部図書館の 地域医療支援活動について
}

A community medical care at the Medical Library of Shinshu University

石坂 憲司 ${ }^{1}$

ISHIZAKA Kenji ${ }^{1}$

1 信州大学附属図書館医学部図書館（干390-8621 長野県松本市旭3-1-1）Tel : 0263-37-2584 E-mail : jja0101@shinshu-u.ac.jp

1 Medical Library of Shinshu University Library (3-1-1 Asahi Matsumoto-shi, Nagano 390-8621)

原稿受理 $(2009-05-15)$

(情報管理５2(4), 207-215)

著者抄録

信州大学附属図書館医学部図書館（当館）では，地域医療支援活動の一環として，平成20年6月より長野県内の信州大 学研修医・研修生派遣病院に対し, 次の新サービスを開始した。（1）JDream II のコソーシアム契約による特別価格 での提供, (2) Web申し込み方式による文献複写物の提供。次に, 平成21年5月より信州大学医学部附属病院内に患者 図書室が開設され，当館からは医学系図書の受入，各種情報提供を行うこととなった。本稿では，新サービスの開始 に至る経緯と現状, および信州大学医学部附属病院患者図書室の概略を報告する。これらの活動により, 関連病院の 医学文献の入手, および病院患者に対する医学文献提供が格段に向上するものと期待される。

キーワード

図書館間相互協力, JDream II, 医学図書館, 地域医療支援, 患者図書館, 医学情報

1.はじめに

信州大学附属図書館医学部図書館（以下，当館） では, 地域医療支援活動の一環として, 次の取り組 みを行っている。

平成20年6月より長野県内の信州大学研修医・研 修生派遣病院（以下, 関連病院）に対し, 次の新サー ビスを開始した。

1) JDream || のコンソーシアム契約

2）Web申し込み方式による文献複写提供

次に, 平成21年5月より信州大学医学部附属病院
内に患者図書室が開設され，当館からは医学関係図 書の受入, 各種情報提供を行う。

本稿では，新サービスの開始に至る経緯と現状， および信州大学医学部附属病院患者図書室の概略を 報告する。

2. JDream II のコンソーシアム契約

2.1 JDream II 導入の経緯

初めに，このたびコンソーシアム契約を推進した

(独) 科学技術振興機構（以下，JST）が提供する 
JDream || のデータベース一覧を表1に示す。

この中で，特にJMEDPlus, MEDLINE，医学・薬学 予稿集全文データベースといつたデータベースが関 連病院にとって利用度の高いデータベースと思われ る。また，抄録からの全文リンクを行っており，医 学系ではメディカルオンラインを契約していれば, JDream II の検索結果からたどり着くことができる。

特定非営利活動法人日本医学図書館協会では, 毎年研修活動の一環として, 医学図書館員基礎研修 会, 医学図書館研究会・継続教育コース等を開催し ている。

平成19年8月，信州大学（以下，本学）にて第14 回医学図書館研究会・継続教育コースが開催され, 研究会において高知大学におけるJDream II コンソー シアム導入の事例が発表された。高知大学の場合, 主に大学側がJDream II の利用料を支払い, 臨床研 修協力病院と共同利用している。この研究会には, JSTの職員が参加されており, 本学に対してJDream ||コンソーシアム導入の提案がされた。

表1 JDream II データベースー覧 $\langle$ http://pr.JST.go.jp./jdream2/database.html〉 *2009年4月現在

\begin{tabular}{|c|c|c|c|c|}
\hline データバース名 & 4R科情執 & 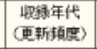 & 牧绿件数区 & 年閔快称件敋 \\
\hline JSTPlus & 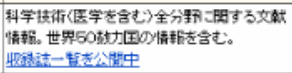 & $\begin{array}{l}1981- \\
\text { (月4回) }\end{array}$ & 672011万件 & 约70万件 \\
\hline JST7580 & 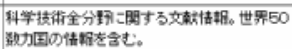 & $\begin{array}{c}1975-1980 \\
\text { (更䉼無) }\end{array}$ & 虹220万件 & 更斩吏 \\
\hline JMEDPlus & 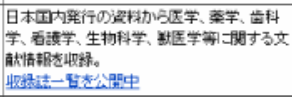 & $\begin{array}{l}\text { 1981- } \\
\text { (月4回) }\end{array}$ & 约 491 万件 & 约 37 万件 \\
\hline JCHEM & 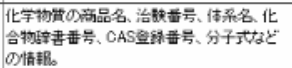 & (月1回) & 约2288万件 & - \\
\hline MEDLINE & 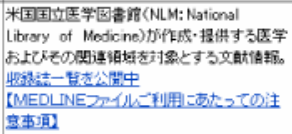 & $\begin{array}{l}\text { 1950- } \\
\text { Gall回) }\end{array}$ & 801.756 万件 & 科50万件 \\
\hline JSTChins & 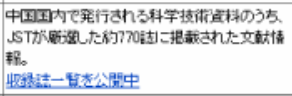 & $\begin{array}{l}\text { 1991- } \\
\text { (月2回) }\end{array}$ & 8529 万件 & 约10万件 \\
\hline JSTPatM & 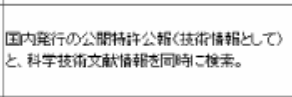 & $\begin{array}{l}\text { fat: } 1993- \\
\text { (月1回) } \\
\text { 文憱:1981 - } \\
\text { (月1回) }\end{array}$ & 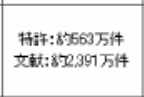 & 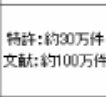 \\
\hline 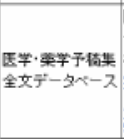 & 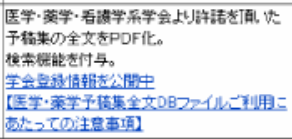 & $\begin{array}{l}1999- \\
\text { (月4回) }\end{array}$ & 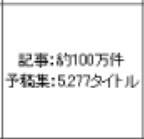 & 稍11 12万件 \\
\hline JAPICOOC & 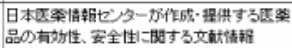 & $\begin{array}{l}\text { 1993- } \\
\text { (月1回) }\end{array}$ & 6?35万14 & - \\
\hline $\begin{array}{l}\text { KENSHU-J } \\
\text { (IFH位.JSTPlus) }\end{array}$ & JSTPluSファイイの研能用ファイイル。 & - & - & - \\
\hline $\begin{array}{l}\text { KENSHU-JMED } \\
\text { (EAPISJMEOPWus) }\end{array}$ & 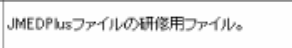 & - & - & - \\
\hline \multicolumn{5}{|c|}{ 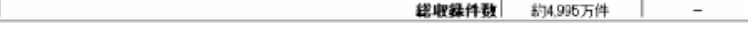 } \\
\hline
\end{tabular}

JDream II 導入により関連病院にとつて有益な医学 文献情報入手の機会を得ることは承知していたが, 予算の確保（継続的な確保を含め）を考慮すると， 高知大学と同様の方式により本学にて導入すること は非常に困難である，といった旨の回答をした。

詳細は3.1にて後述するが, 長野県内の病院図書 館間の活動, 県内病院における信州大学医学部附属 病院（以下，信大病院）の立場などを話す中で, 本 学, 県内病院, JSTの3者がうまく共同歩調を取るこ とができないか，模索した。

主に，電話とメールにより，何度か当館とJSTの 間で打合せを行い，最終的に平成20年2月，JSTよ り本学はJDream II の本学利用料のみ負担し, 関連病 院は通常価格より安価に導入できる提案がされた。 このことを受けて, 本学医学部にて検討の結果, 当 館が中心となり積極的に関連病院へのJDream II コン ソーシアムの参加を推進することにした。

\section{2 利用講習会とJDream || トライアル}

平成20年3月, 関連病院に対し, 利用講習会, お よびJDream II トライアルの実施について広報を行っ た。

\subsection{1 利用講習会}

本学は, 長野県内各地に5キャンパスを有する。 その特性を利用し, 平成20年4月, 長野, 松本, 上 田，南箕輪の4キャンパスで5回の利用講習会を実施 した。講師はJSTおよび代理店から招請した。1回あ たり1時間程度の講習を行い，JDream Iの基本的な 検索方法, 医中誌Web版との違いについて説明した。 本学としてもJDream II は初めて導入することもあ り, 学内者および関連病院担当者を対象とした。全 部で108人の参加があり, その内, 関連病院からの 参加者は12人であった。

\subsubsection{JDream II トライアル}

平成20年4月～5月の間, JDream II ライアルを 
実施した。27病院の参加があり, 多数の利用があつ たとJSTから報告があった。

\subsection{JDream II コンソーシアム契約の現状}

高知大学の場合, 当初すべて大学側で経費負担し ていたが，現在は参加病院も参加費として一部負担 している11。

本学の場合は, JSTおよび代理店との間で, 当館, 関連病院側とも，各々独立契約とした。通常，病院 がJDream II を導入する際の料金（病院等医療機関向 け固定料金)2)は, 年間30万円 (同時アクセス3) だが, 今回のコンソーシアムの提案は, 次の2通りである。

・年間10万円 (同時アクセス 1)

・年間15万円 (同時アクセス2)

このことにより，関連病院は JDream IIを低価格 で導入できることとなった。

なお，20年度は13病院がコンソーシアムに参加 した。

\section{Web申し込み方式による文献複写提供}

\section{1 新サービス導入の背景}

JDream II コンソーシアム参加の13病院, および 19年度以前からの通常契約の3病院に対して, 要望 があればWeb申し込み方式による文献複写提供を行 うこととした。この文献複写提供は, 当館の所蔵資 料はもとより，当館に所蔵していない資料も他館か ら取寄せ提供するものである。

JDream || 導入の直接的な契機は，前述のとおりだ が，このWeb申し込み方式による文献複写提供と合 わせた新サービス導入の背景をたどってみる。

\subsection{1 長野県内の病院図書館間の連携}

長野県は, 北海道, 岩手県, 福島県に次ぐ面積を 持つ広い県である。周囲は山脈に囲まれ, 各盆地間 も急峻な峠を行き来しなければならず，古来より長 野県の地形は地域交流の妨げになっている。その地
形の影響もあったと推察されるが, 県内の病院図書 館間の交流は少なかった。しかし, 近年始まった病 院機能評価の受審等もあり, 図書館関係者の中では, 図書館サービスの拡大・向上を目指し, 文献複写入 手を含めた図書館間のネットワークの必要性につい ての気運が高まっていた。

そのような中,「長野県医学図書ネットワーク」は, 平成17年12月に, 病院図書室等の充実と向上に努 め, 医療情報活動を通じて地域医療の発展に献身す ることを目的に発足した。会員は, 当館を含め当初 病院関係者13病院14名, 大学図書館2館2名の計15 施設16名で，平成20年4月には18施設20名となっ た。これらの病院は地域中核病院であり, 本学の研 修医や医学部学生の研修先病院として, 本学とも関 係があった。

当ネットワークの発足により, 情報交換の場が作 られた。研修会も年2回のペースで開催され，顔の 見えるネットワークとなり, 業務の問題点を相談し あえる仲間, スキルアップの場として, 大いに活用 されているぶ。

この活動により, 県内でのILL（図書館間相互貸借） も活発となった。特に平成19年度から本学で開始し た料金後納制度により, 文献提供に要する期間が従 前の約2週間から2日程度と短縮された。また, 本学 で契約している多くの電子ジャーナルが利用提供で き, 文献入手が格段に向上し, 結果, 多くの病院図 書室から依頼が来るようになった。

\subsection{2 卒後臨床研修制度}

長野県の卒後臨床研修制度は, 信大病院を核とし て, 県内の地域中核病院亡連携している。2年の研 修期間のうち 1 年を信大病院, 残り1年を関連病院で 行っている。本学と関連病院との電子ジャーナル, データベース等の情報提供環境の差が大きく, 改善 を求める声が上がっていた。 


\section{1 .3 料金後納制度}

主に大学図書館では, 自館に利用者の要求する資 料が無い場合, 国立情報学研究所のNACSIS-ILLとい う, 図書館間相互貸借サービス（文献複写，および 図書の貸借の依頼・受付）のシステムを用い，利用 者に資料提供を行っている。

本学では, 国立大学法人化後の平成16年度〜18 年度の間, NACSIS-ILLの非相殺参加館（主に病院， 公共図書館等）への料金決済は，現金書留送付によ る前払い方式としていた。

当館には県内外の病院から後払い方式への強い要 望が寄せられており，平成19年度から料金後納制度 を実施することとした。

このことにより, 病院側に対し, 文献複写物の迅 速な提供, 支払処理の簡略化等のメリットが生じた。

詳細は3.3にて後述するが，非相殺参加館から当 館に申し込みのあった文献複写受付数が, 飛躍的に 増加した。

\subsection{Web申し込み方式による文献複写提供の現状}

\subsubsection{Web申し込み方式の概略}

大分大学医学図書館は, 本学のWeb申し込み方式 による文献複写提供と同様のサービスを, 試行サー ビスを経て，平成20年1月より本番実施している。

本学では，料金後納制度による文献複写物の提供 の実績を考慮し，試行運用をしなくても大きな混 乱がないと判断し，平成20年6月から本番運用とし た。ただし，業務量の予測が甚だ困難であり，当面 はJDream II 契約病院を対象とした。

申し込みから文献提供までの流れを図1に示す。 なお，大分大学では，個人単位による利用者IDの発 行, 料金請求を前払い・後払いの併用, 電子ジャー ナルを文献複写のサービス対象外としている4)。本 学では, 病院単位によるIDの発行, 料金請求は後払 いのみ，電子ジャーナルも複写の対象（ILL可と契約 されているもの）としている点が，大きな相違であ る。
関連病院

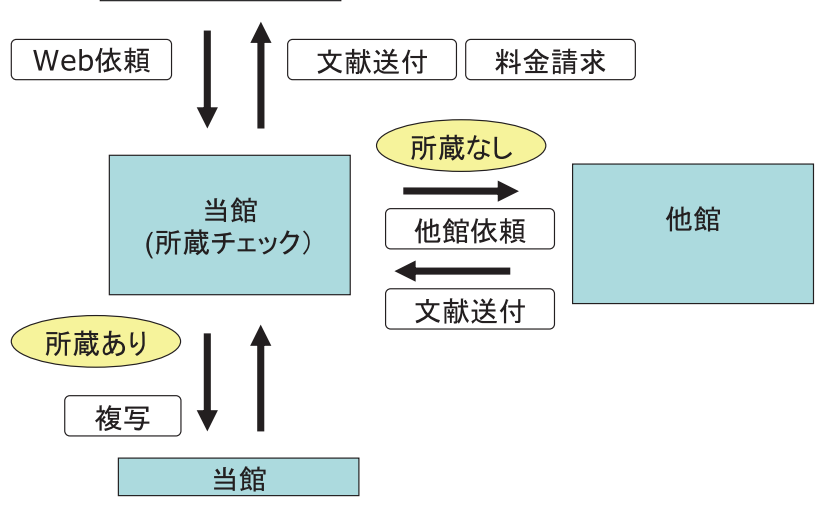

図1 申し込みから文献提供の流れ図

\subsubsection{Webによる申し込み}

現在, 当館では, 通常の非相殺参加館からの文献 複写の受付は,Faxにより行っているが，書誌事項 を目視の上, 申し込みデータを入力し, 所蔵確認を 行っている。このたびWeb方式を採用したことによ り, 容易な所蔵確認, 文献複写依頼時に申し込みデー 夕を流用できるといったメリットがある。

初めに，本サービスを希望する病院は，本サービ スの利用申請書を提出する。利用申請書受理後, 当 館では, NTTデータの図書館システムであるNALISに よる利用者登録を行い, 申請病院に対し, 承認書の 発行を行う。

次に, すべて後払い方式としているので, 文献複 写料金後納許可の申請をする必要がある。希望する 病院からは申請を行い, 当館から承認書を発行して いる。

文献複写の入手のために, 毎回行う処理は, 病院 側からNALISのWeb申し込み機能を使い, 文献複写 の申し込みを行う。

病院側から複写依頼があると, 初めに当館の文献 複写依頼担当は, 当該資料の所蔵確認を行う。当館 所蔵の場合は, NALIS口ーカル機能を用いて当館自 身に依頼を行い, 文献複写受付担当が現物の複写作 業を行う。当館に所蔵している場合, 1件あたりの 
請求料金は, 1枚35円十依頼病院までの送料である。

当館に所蔵が無い場合は,NALISによる学外文献 複写依頼機能を用い，他所蔵館より文献を入手す る。この場合の依頼病院への請求料金は，他館から 入手するために要した料金に，当館から依頼病院ま での送料を加えた実費であり, 手数料は請求してい ない。

当館では，平成19年9月より，依頼病院に文献複 写物を送付する際，ヤマト運輸のクロネコメール便 を利用している。A4サイズ, 厚さ1cmまでであれば, 80円（速達の場合，100円加算）であり，25グラム を超過した際の郵送と比べると安価である。

四半期ごとに依頼病院からの依頼データの集計を 行い，それを元に本学から依頼病院に対し，請求書 を発行している。

依頼病院にとって, 文献複写料金後納許可の申請 の際に若干期間を要するが，その後は現金による料 金前払いと比べてかなり早く文献を入手することが できる。

\subsection{3 処理件数}

平成20年6月より新サービスを開始したが，20年 7月より実際の文献複写処理が発生した。平成20年 7月〜21年3月の間，6病院が参加し，自館所蔵に よる処理件数が268件, 他館依頼による処理件数が 258件，合計526件発生した。

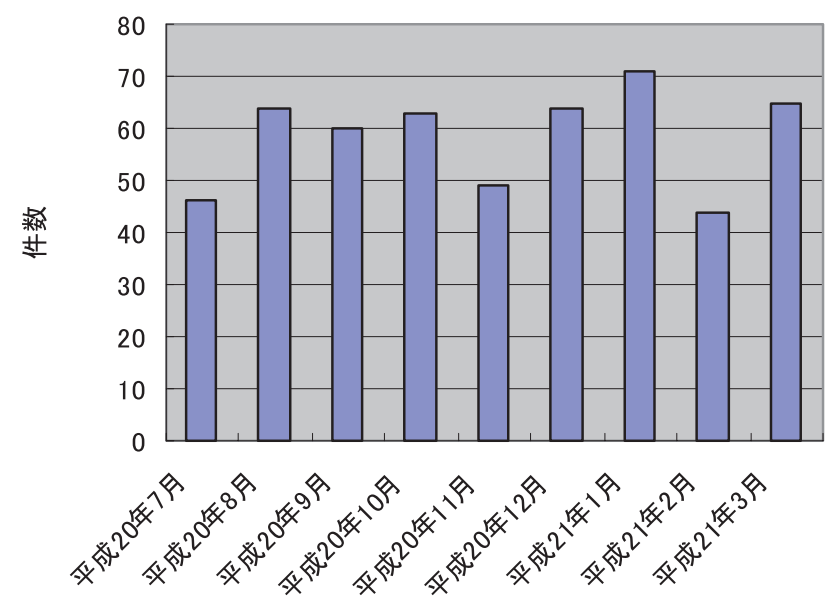

図2 文献複写処理件数（平成20年7月～21年3月）
月別の件数を図2に示す。毎月, 60件前後の安定 した数値となっている。

利用病院からは, 文献をより早く入手したい, 依 頼した文献の書誌, 金額等の電子データを入手した いといった要望がある。

\section{3 非相殺参加館, および県内機関からの文献 複写処理}

平成16２0年度の間，非相殺参加館から申し込 みのあった文献複写の処理件数, および県内機関か らの件数を表2に示す。

全体件数の伸びは，表2のとおり平成19，20年度 は, 前年度比の約3倍程度に増加しているが, 県内 機関からの件数に注視してみる。

17年度から18年度にかけて, 県内機関からの依 頼による処理件数は, 31件から140件に増加した。 この主要因は, 「長野県医学図書ネットワーク」の 発足によるものと考えられる。

18年度から19年度にかけての処理件数は，140件 から450件と約3.2倍に増加している。19年度は,「長 野県医学図書ネットワーク」の活動が浸透し, 料金 後納制度を開始したことが大幅な数值の上昇に反映 している。

そして，19年度から20年度にかけての処理件数 は，450件から1,225件と約2.7倍の増加となった。 現金前払いのみの運用をしていた16〜18年度の間 の平均值 (60件) と比べると, 約20倍と驚異的な 数值の伸びとなっている。これは, さらなる新サー ビスの実施による効果と言える。

20年度から始めた新サービスは，前述のとおり， JDream II のコンソーシアム契約の推進とWeb申し

表2 非相殺参加館からの文献複写受付数（平成16～20年度） *かっこ内は県内機関からの処理件数で, 合計の内数

\begin{tabular}{|l|r|r|r|r|r|}
\hline & 平成16年度 & 平成17年度 & 平成18年度 & 平成19年度 & 平成20年度 \\
\hline 前払 & 122 & 171 & 212 & 19 & 41 \\
\hline 後払 & & & & 555 & 1,378 \\
\hline 合計 & 122 & 171 & 212 & 574 & 1,419 \\
(県内) & $(9)$ & $(31)$ & $(140)$ & $(450)$ & $(1,225)$ \\
\hline
\end{tabular}


込み方式による文献複写提供によるものである。す なわち, JDream IIによる文献検索をした結果, 原文 献が必要な場合, 当館の所蔵の有無に関係なく，申 し込みをして全文を入手する，といったスタイルが 確立されたわけである。

このことを考慮すると, JDream IIを関連病院が導 入したことにより，医学関係文献の良質な検索がで き，必要な文献がすぐ見つかる，といつた大きな効 果があったと言える。

飛躍的な文献複写の増加は, 地域医療支援の向上 に寄与していると考えられる。

\section{4. 信州大学医学部附属病院患者図書室の 概略}

\section{1 概要}

信州大学医学部附属病院患者図書室（愛称，「こ まくさ図書室」，以下，当院図書室）は，平成21年 5月7日，信大病院の新外来診療棟のオープンと同日 に開室した。

当院図書室は，信大病院の新外来診療棟1階に設 けられたが，国立大学法人である信大病院と自治体 である松本市との業務連携の上に成立しているユ ニークな図書室である。

図3に信大病院と松本市との業務連携の概要図を 示す。

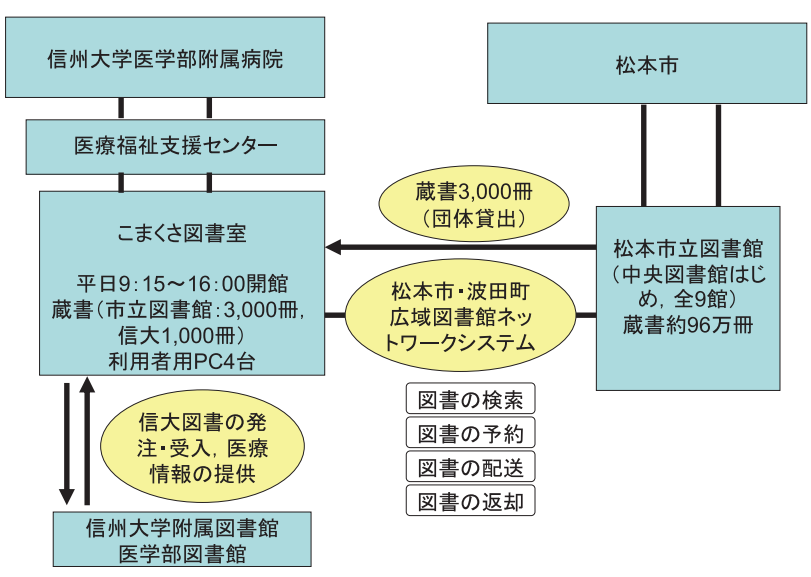

図3 信大病院と松本市の業務連携の概要図

\section{2 設置の経緯}

本学は教育, 研究, 国際交流とともに地域貢献を 目標の一つに掲げており, 地域貢献に対して大学を あげて傾注している。信大病院においても, 『地域 における医療と福祉の向上に寄与する』ことを目標 のひとつとしている。

また, 信大病院は特定機能病院, 高度救命救急也 ンター等, さまざまな指定病院となっている。平成 18年8月, 信大病院は都道府県がん診療連携拠点病 院に指定されたが，患者図書室は設置されていな かった。そこで, 新外来診療棟の建築を機に, 当院 図書室の設置に向けて, 病院長の指示のもと信大病 院医療福祉支援セン夕ー（以下，センター）が担当 となり，開室の準備を開始した。

平成19年, センターと当館との間で, 当院図書室 の位置づけについて何度か打合せを行った。当館の 分室としての運用は, 人員, 予算的に極めて困難で あり，また配架・貸出すべきと判断した図書の範囲 は, 医学的な専門書から, 入院患者向けの小説など の一般図書と, 多岐にわたる。松本市立図書館（以 下，市立図書館）では団体貸出用図書を常備してお り，それを借用し当院図書室に一般図書を配架 ·貸 出するといった提案がなされた。ところが, その提 案を充足するには, 信大病院で購入する医学的な専 門書と市立図書館の一般図書を同時に管理・運用す る必要がある。

最終的には, 信大病院購入図書を市立図書館の図 書館システムへ登録することにより, 当院図書室の システムの一元化を図ることができる見通しが立 ち, 市立図書館との連携を考慮した運用体制の提案 が図られた5)。

平成20年1月, 本学から松本市長に陳情し, 市立 図書館との連携の基本合意がなされた。

同年7月, 本学内にて病院長, セン夕一長, 松本 市中央図書館長の協議により, 経費負担, 協定書等 を決定した。

そして, 平成21年3月23日, 松本市と信大病院の 
間で, 『松本市中央図書館及び信州大学医学部附属 病院患者図書室における図書館業務の連携に関する 協定書』(以下，『協定書』）が締結された。

\section{3 目的}

図書室の設置の目的は，松本市，および隣接する 波田町により構成されている図書館ネットワークシ ステムにより, 松本市, 本学が行う図書館業務を連 携して実施し，入院患者，外来患者及びこれら患者 に関係する市民等の利用に供し, その教養, 調査研 究，レクリェーション等に資することである(『協 定書』より)。

\section{4 組織・開館時間}

当院図書室は, 次の職員の組織からなる。

1. 患者図書室長 (信大病院長)

2. 副患者図書室長 (センター長)

3. 図書館司書2名（センター所属職員）

図書館司書2名については，9時～13時勤務と12 時30分〜16時30分勤務の2交代制である。

開館時間は，平日午前9時15分から午後4時まで である。

\section{5 資料・図書館システム}

資料は，市立図書館から3,000冊，本学から 1,000

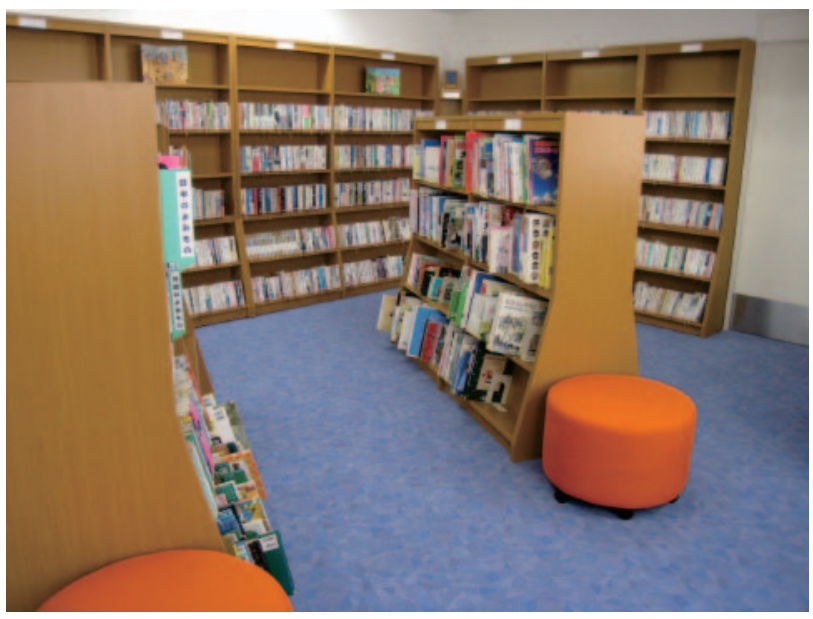

図4当院図書室（書架とフロアー）
冊の合計4,000冊を準備する。市立図書館側からは 団体貸出による一般図書であり，定期的に入れ替え を行う。本学からは医療・看護関係図書であるが, 18年度から準備を行ってきており，20年度末現在 で約600冊程度用意することができた。当院図書室 の内部の様子を図4, 図5に示す (2009年4月30日撮 影)。

図書館システムは, 市立図書館で運用している業 務システムを使用している。

本学提供の図書は, 市立図書館資料と資料ラベル 等同様の装備をし，市立図書館の蔵書データベース に登録している。なお, 本学の図書資産であるので, 図書の内側には，本学資料を明示した資料ラベルを 貼付し,NALISの蔵書データベースにも登録してい る。

このことにより, 市立図書館提供の図書を加えた, 室内配架の約4,000冊の図書を市立図書館の利用者 カードを使って, 貸出することができる。辞書, 事 典類といつた参考図書については, 貸出はできない。

市立図書館は, 中央図書館をはじめ全部で9館か ら構成されており, 約96万冊の蔵書がある。

当院図書室では, 市立図書館の分館的機能を有し ており, 市立図書館からの図書の取寄せ, 返却といつ たこともできる。

このことにより, 入院患者らが一般図書をはじめ,

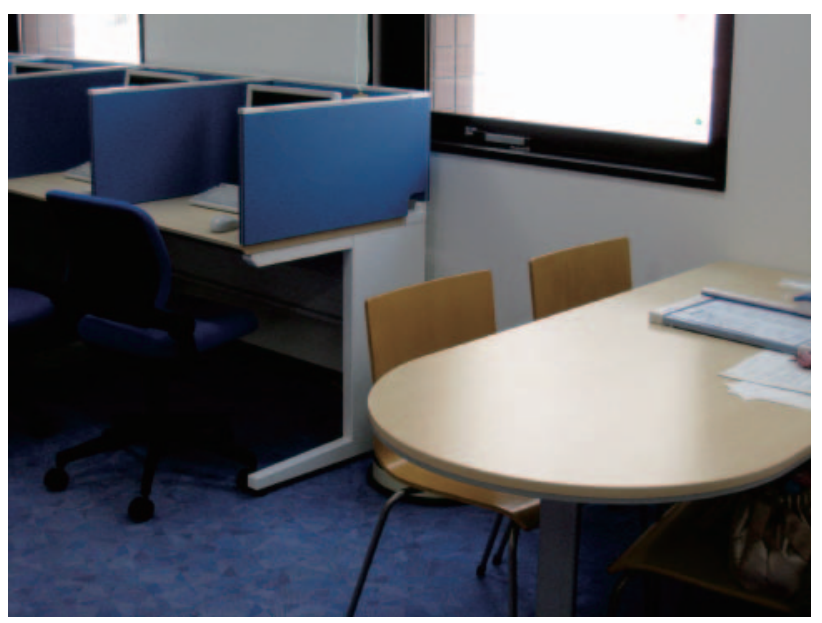

図5 当院図書室（利用者用PCと閲覧席） 
病気や健康, 看護に関する基本的な知識を得ること ができ，患者サービスの大きな向上が見込まれる。

\section{6 当館との連携}

当館からは，当院図書室に対し，信大側の図書の 発注・受入, 選書補助の相談等の業務の協力を行っ ているほか, 当院図書室利用者が, より専門的な図 書を求める場合, 貸出を含め対応する予定である。

なお，当館が行っている発注・受入の手順は次の 通りである。

1）センター職員による選書

2）図書館流通センター (以下, TRC) のTOOLi（ツー ルアイ）を利用しての発注処理

3）当館の図書館システ *TRCからは, 請求ラベル, 資料ラベル等が装備済 みで納品

4）本学の財務会計システムによる支払処理

5）当館からセンターへ図書の引き渡し

\section{5. 今後の展望と課題}

\subsection{JDream II のコンソーシアム契約}

平成20年度末に, 21年度の参加に向けて, 関連 病院に広報した。その結果, 21 年度は, 前年度と 比べて2病院増え, 15病院のコンソーシアム契約と なった。微増ではあるが，拡大したことは事実であ り，少しずつ関連病院にJDream || を導入するメリッ トが浸透してきたと言える。

ただ，今回の広報活動の中で，JDream IIがどのよ うなデータベースか知らない病院担当者もおり，も う一度広報のあり方を見直す必要があると考えてい る。

\subsection{Web申し込み方式による文献複写提供}

前述のように処理件数が増大しており, 当館の運
用体制を考慮し, 当面サービス対象はJDream II 契約 病院のままとした。

次の段階は, JDream II 契約病院をサービス対象と いう制限をなくし，関連病院すべてを対象にすべく 検討したい。

業務の最適化を図るために, 文献複写全体の処理 方法の見直しも必要だが，場合によっては，当館職 員の業務分担，あるいは増員といったことも視野に 入れなければならない。当館の業務全体に非常に大 きな影響を持つサービスであり, 慎重を期したい。

\section{3 当院図書室}

現段階では, どのような課題が発生するのか不明 だが，まずは着実な運用が第一と思われる。

当面は，運用内規をより綿密なものにしていく必 要があるが，運用状況を勘案して適宜対応していく ことになる。

今後, 当館としてもできる限りフォローしていき たいと考えている。

\section{6. おわりに}

当館の新サービスを開始したことによる, 関連病 院に対する地域支援医療活動は, 地域医療の学術情 報提供の質的向上を図るためのインフラ整備を提供 したと言える。

また，当館の当院図書室に対する連携は，新たな 地域医療支援活動になりうると考えている。

最後に, 本稿の主旨と少し離れるが, 本学が20年 度より導入したJDream IIは, 学内利用者, 特に学生 に大きな反響があった。医学部はもとより, 理工系 学部の利用が多く, 全キャンパスで年間約20,600回 の検索回数があった。学内利用者の教育・研究活動 にも役立てた意義は大きい。

ここに関係各位に謝意を表する。 
1）田所千峰子. 臨床研修協力病院とのデータベース共同利用：高知大学総合情報センター (図書館) 医 学部分館の例. 医学図書館. 2007, vol. 54, no. 1, p. 69-72.

2）科学技術振興機構。“病院等医療機関向 け固定料金”. http://pr.JST.go.jp./pricelist/jdream2-3.html,（参照 2009-04-30).

3）前澤好広．長野県でのネットワーク活動について。病院図書館. 2006, vol. 26, no. 2, p. 54-55.

4) 山田哲敬. 大分大学『医学文献デリバリーサービス』による地域貢献への試み. 医学図書館. 2008, vol. 55, no. 3, p. 224-228.

5）折井匡．信州大学附属病院に市立図書館の機能を持った患者図書室ができます．全国患者図書サービ 又連絡会会報. 2009, vol. 15, no. 4, p. 65-68.

Author Abstract

In June 2008, the Medical Library of Shinshu University started on the following two services called the New Service toward hospitals in Nagano accepting residents of Shinshu University as a support to the community medical care; 1.JDream II service at the special price as a consortium, 2.Document delivery service by applying through the internet. In May 2009, the hospital library has been established in the Shinshu University Hospital. Our services for them are purchasing medical materials and giving various information. Here, I report the course and the present of the new service and also an outline of the Shinshu University Hospital Library. I expect that these services improve the document delivery service for the related hospitals and for the patient.

Key words

library cooperation, JDream II, medical library, community medical care, patients' library, medical information 